\title{
State of antioxidant system in urogenital trichomoniasis and membranotropic effect of metronidazole
}

\author{
H.K. Kondakova, H.O. Semko, O.V. Levytska, V.M. Tsymbal \\ $S E$ «Institute of Dermatology and Venereology of NAMS of Ukraine»
}

\begin{abstract}
The objective of this work was to study the activity of glutathione peroxidase, glutathione reductase and the level of sulfhydryl groups in erythrocytes of patients with urogenital trichomoniasis and the effect of metronidazole on the degree of osmotic and peroxide resistance of erythrocytes from healthy donors.

We examined 15 patients with urogenital trichomoniasis and 20 healthy volunteers. We studied native preparations, and also carried out a culture method using the Johnson-Trussel nutrient medium (CPLM) to identify Trichomona vaginalis. The activity of glutathione reductase, glutathione peroxidase and the level of total sulfhydryl groups were determined in erythrocytes of peripheral blood. The membrane effect of metronidazole was evaluated in in vitro experiment by the degree of osmotic and peroxide resistance of erythrocytes from healthy people. It has been established that a significant decrease in glutathione reductase and glutathione peroxidase activities in erythrocytes is observed, which indicates a violation of the antioxidant system in this pathology. It was shown in vitro experiment, that metronidazole in low concentration $(80 \mu \mathrm{mol} / \mathrm{I})$ has the ability to inhibit erythrocyte hypotonic hemolysis, and high concentration $(250 \mu \mathrm{mol} / \mathrm{l})$ leads to a decrease in osmotic and peroxide resistance of erythrocytes. Thus, inhibition of the activity of the enzymatic link of the antioxidant defense is observed in urogenital trichomoniasis, which is one of the mechanisms for the development of pathology at the cellular level in this disease. It has been shown that the isolated membranotropic action of metronidazole depends on its concentration - the drug at low concentration is able to inhibit hypotonic hemolysis of erythrocytes, and high concentration makes them more sensitive to the osmotic and peroxide hemolysis. The obtained results should be taken into account in the development of complex methods of therapy for urogenital trichomoniasis.
\end{abstract}

Key words: urogenital trichomoniasis, antioxidant system, osmotic hemolysis, peroxide hemolysis, metronidazole

DOI: 10.33743/2308-1066-2021-2-8-11

Therapy of urogenital infections remains a topical and discussed problem of venereology, obstetrics and gynecology, and urology. The main subject of discussion regarding trichomoniasis is the choice of the optimal antiprotozoal drug [6]. There is the large arsenal of fast-acting and effective antiprotozoal agents. All recommended drugs belong to the nitroimidazole group. The ancestor, which has not lost its meaning today, is metronidazole (1(2'-hydroxyethyl)-2-methyl-5-nitroimidazole) [5, 14].

Metronidazole (MZ) is an effective broad-spectrum chemotherapeutic antimicrobial and antiparasitic drug that inhibits the growth of anaerobic organisms. In addition, it exhibits cytoprotective and immunomodulatory properties. MZ can affect various components of innate and acquired immunity [11].

While the mechanism of the antibacterial action of MZ is well understood, the mechanism of its protective action is practically not studied. There is reason to believe that the protective effect of $\mathrm{MZ}$ is due to its stabilizing effect on the structure of the network of hydrogen bonds of water in the near-membrane region or at the surface of biomacromolecules. The result of this is the termination of the access of the substance to the membrane, integral enzyme or receptor. Probably, the protective effect of the drug on the cells of warm-blooded animals is associated with this [10].
Analysis of recent literature indicates that oxidative stress accompanies and/or is one of the pathogenetic links in the development of many types of infectious pathologies, including trichomoniasis. It has been shown that the processes of lipid peroxidation are enhanced in almost all tissues of the male genitourinary system during this infection, which leads to the destruction of cell membranes [5, 7, 9].

The objective of this work was to study the activity of glutathione peroxidase (GP), glutathione reductase (GR) and the level of sulfhydryl groups (SH-groups) in erythrocytes of patients with urogenital trichomoniasis and the effect of MZ on the degree of osmotic and peroxide resistance of erythrocytes from healthy people.

\section{Materials and methods}

We examined 15 patients with urogenital trichomoniasis. The study included persons aged 17 to 60 years old who applied for examination for sexually transmitted infections, including Trichomonas vaginalis. To identify $T$. vaginalis, we studied native preparations [15], and also carried out a culture method using the Johnson-Trussel nutrient medium (CPLM) [8]. The control group consisted of 20 healthy donor volunteers.

GR, GP activities and the level of total SH-groups were determined in erythrocytes. 
Hemolysate was prepared as follows: $1.8 \mathrm{ml}$ of distilled water cooled to $0{ }^{\circ} \mathrm{C}$ was added to $0.2 \mathrm{ml}$ of plasma washed and packed erythrocytes. $3 \mathrm{ml}$ of precipitating solution was added to the hemolysate to precipitate proteins, the samples were thoroughly mixed and after 20 minutes of standing at $21^{\circ} \mathrm{C}$ were filtered through a coarse filter.

The level of total SH-groups in the hemolysate was determined using Elman's reagent [4].

GP activity (EC1.11.1.9) was determined spectrophotometrically. To $0.2 \mathrm{ml}$ of hemolysate add $1 \mathrm{ml}$ of phosphate buffer of the following composition: $0.3 \mathrm{M}$ phosphate buffer ( $\mathrm{pH} 7.4$ ) with $12 \mathrm{mM}$ sodium azide and $6 \mathrm{mM}$ EDTA, $0.5 \mathrm{ml} 2.5 \mathrm{mM}$ reduced glutathione, $0.5 \mathrm{ml}$ of $1.8 \mathrm{mM}$ hydrogen peroxide. After 2 minutes, the reaction is stopped by adding $1 \mathrm{ml}$ of $10 \%$ trichloroacetic acid. The hemolysate is replaced with $0.2 \mathrm{ml}$ of distilled water in the control sample. The tubes are centrifuged for 15 minutes at $3000 \mathrm{rpm}$. The transparent supernatant is poured off and the measurement is carried out on an SF-46 spectrophotometer at a wavelength of $260 \mathrm{~nm}$ relative to the control sample [4].

Measurement of GR activity (EC1.6.4.2) was carried out spectrophotometrically on SF-46 at $340 \mathrm{~nm}$. The reaction rate was judged by the drop in optical density as a result of NADPH oxidation. $1.5 \mathrm{ml}$ of a $0.1 \mathrm{M}$ solution of potassium chloride, $0.5 \mathrm{ml}$ of $0.2 \mathrm{M}$ phosphate buffer ( $\mathrm{pH} 7.4$ ), 0.25 $\mathrm{ml}$ of $0.08 \mathrm{M}$ EDTA solution, 0.05 hemolysate, $0.1 \mathrm{ml}$ of 2 $\mathrm{mM} \mathrm{NADPH}_{2}$ solution. The unit of activity (E) was the amount of the enzyme catalyzing the formation of $1 \mu \mathrm{mol}$ of the reaction product in $1 \mathrm{~min}$ at $25^{\circ} \mathrm{C}$ [4].

Membranotropic action of $\mathrm{MZ}$ was assessed in vitro by the degree of osmotic and peroxide resistance of erythrocytes of 10 healthy people. In the experiments, erythrocyte suspensions obtained from donor blood stabilized with $0.109 \mathrm{M}$ sodium citrate solution were used by washing three times in physiological solution (Darnitsa, $0.15 \mathrm{M} \mathrm{NaCl}$ solution, $\mathrm{pH}$ 7.4) for $10 \mathrm{~min}$ (OPn-3 centrifuge, $3000 \mathrm{rpm}$ ). The initial suspension of erythrocytes was obtained by adding the cell pellet to physiological saline 1:10. We used intact erythrocytes and preincubated for 15 minutes with metronidazole at a concentration of $250 \mu \mathrm{mol} / 1$ and $80 \mu \mathrm{mol} / 1$ in the experiment. $50 \mu$ of the initial suspension of erythrocytes was introduced into $1.0 \mathrm{ml}$ of $\mathrm{NaCl}$ solution $(77 \mathrm{mmol} / \mathrm{l}$ and 60 $\mathrm{mmol} / \mathrm{l}$ ) for $15 \mathrm{~min}$, then centrifuged at $3000 \mathrm{rpm}$ for $3 \mathrm{~min}$. The degree of hemolysis was estimated by the optical density of the liquid obtained after sedimentation non-hemolyzed erythrocytes, and expressed as a percentage in comparison with the optical density of samples in which hemolysis of erythrocytes was caused by distilled water $(100 \%$ hemolysis). Osmotic hemolysis of erythrocytes was recorded on a spectrophotometer SF-46 at a wavelength of $543 \mathrm{~nm}$.

The resistance of erythrocytes to the action of peroxide was determined by the method of S.S. Mikhailov et al. [3]. The method for determining the peroxide hemolysis of erythrocytes was carried out as follows: $0.1 \mathrm{ml}$ of $2.2 \%$ hydrogen peroxide solution was added to the erythrocyte suspension, the samples were incubated for min at $37^{\circ} \mathrm{C}$ with constant shaking. The degree of hemolysis was judged by the optical density $\mathrm{E}_{536}$, which directly reflects the concentration of hemoglobin. The measurements were carried out on an SF-46 spectrophotometer.

The results were statistically processed using the Statistica software. The significance of differences in the mean values was assessed using parametric (Student's t test) and nonparametric (Wilcoxon's t test) tests [13].

\section{Results and their discussion}

Glutathione and glutathione-dependent enzymes play a significant role in the antioxidant defense system and redoxdependent regulation. Glutathione, as a cofactor, is part of the enzymes of the glutathione system, which destroy hydrogen peroxide (GP), maintain the pool of reduced glutathione (GR), providing complex antioxidant protection [1,12].

Thiols occupy an important place among tissue antioxidants, since $\mathrm{SH}$-groups are highly reactive, being easily oxidized, they protect cell components from damage, exhibiting both antiradical and antiperoxide effects. The performed determination of the level of common SH-groups in the blood of patients with trichomoniasis showed that this indicator does not undergo pathological changes (Table 1).

The study of the activity of glutathione-dependent enzymes GP and GR in erythrocytes showed that patients with urogenital trichomoniasis have a significant decrease in the activity of these enzymes. The activity of GP in the erythrocytes of patients was reduced by 1.13 times $(\mathrm{p}<0.05)$, and GR - by 1.46 times $(\mathrm{p}<0.05)$ (Table 1$)$ compared with the group of healthy people. At the same time, the level of $\mathrm{SH}$-groups remains at the level of the control values, which is insufficient to neutralize the hyperproduction of reactive oxygen species (ROS).

$\mathrm{GP}$ is of paramount importance in protecting the cell from the generated hydrogen peroxide [1,12]. It participates simultaneously in two lines of enzymatic protection of cells: on the one hand, from oxidative stress, and on the other hand, in the detoxification of the lipid peroxidation (LPO) products, fatty acid hydroperoxides and peroxides of other substances. GR is the supplier of reduced glutathione in the cell and works in antiphase with GP, plays a crucial role in protecting cell membrane structures, especially from exogenous damage. Probably, the observed decrease in the GR activity in the blood of patients with trichomoniasis is associated with the functional use of this enzyme in blood cells to replenish the content of reduced glutathione, which is intensively consumed by cells. At the same time, it can be assumed that changes in the activity of glutathione-dependent enzymes are a consequence of the modifying action of ROS and may indicate the involvement of the glutathione system in the mechanisms of pathology development in urogenital trichomoniasis at the cellular level.

It is known that the use of antimicrobial drugs in the treatment of inflammatory processes is accompanied by the manifestation of antibiotics of various non-antibacterial effects [2]; therefore, the choice of the drug must be carried out taking into account its available antimicrobial and non-antibacterial properties. Some authors consider MZ to be a pro-drug because by itself, it does not exhibit bacteriostatic action and does not affect the state of polynucleotides in higher organisms. It regulates the level of pro- and anti-inflammatory cytokines, has an anti-inflammatory effect, inhibits the formation of ROS, and affects delayed-type hypersensitivity [11].

Table 1. Activity of GP and GR in erythrocytes of patients with trichomoniasis and healthy donors ( $M \pm m$, Student's test)

\begin{tabular}{|l|c|c|c|}
\hline \multirow{2}{*}{ Examined groups } & \multicolumn{3}{|c|}{ Subjects } \\
\cline { 2 - 4 } & $\begin{array}{c}\text { Level of } \\
\text { SH-groups, } \\
\text { mmol/l }\end{array}$ & $\begin{array}{c}\text { GP activity, } \\
\text { mmol/l }\end{array}$ & GR activity, E/I \\
\hline Healthy donors, $\mathrm{n}=20$ & $88,37 \pm 4,66$ & $6,65 \pm 0,31$ & $33,33 \pm 1,02$ \\
\hline $\begin{array}{l}\text { Patients with urogenital } \\
\text { trichomoniasis, } \mathrm{n}=15\end{array}$ & $86,80 \pm 5,97$ & $\begin{array}{c}5,88 \pm 0,30^{*} \\
\mathrm{p}<0,05\end{array}$ & $\begin{array}{c}22,75 \pm 1,92^{*} \\
\mathrm{p}<0,001\end{array}$ \\
\hline
\end{tabular}

Note: * the difference is significant relative to the group of healthy donors. 
Taking these facts into account, we studied the effect of different doses of $\mathrm{MZ}$ in vitro on the state of osmotic resistance of erythrocytes from healthy donors. Two concentrations of a hypotonic $\mathrm{NaCl}$ solution were selected for a quantitative assessment of the hypotonic stability of erythrocytes: $77 \mathrm{mmol} / \mathrm{l}$, which corresponded to the onset of the development of the hemolytic process, and 60 $\mathrm{mmol} / \mathrm{l}$, which corresponded to approximately $50 \%$ hemolysis. Erythrocytes preincubated with $\mathrm{MZ}$ at concentrations of $80 \mu \mathrm{mol} / \mathrm{l}$ and $250 \mu \mathrm{mol} / \mathrm{l}$ were added to hypotonic media.

Table 2 shows that the $\mathrm{MZ}$ dose of $80 \mu \mathrm{mol} / \mathrm{l}$ protects erythrocytes from destruction, it demonstrates a membrane-stabilizing effect. In the same time an increase in erythrocyte hemolysis occurs at the MZ concentration of $250 \mu \mathrm{mol} / \mathrm{l}$ in the incubation medium. A similar picture is observed at both concentrations of hypotonic media.

$\mathrm{MZ}$, due to its amphiphilic nature, is able to integrate into the erythrocyte membrane and, according to the authors of [10, 11], the basis for the manifestation of the antihemolytic activity of amphiphilic substances is probably their ability to disorganize the erythrocyte membrane when embedded in it, and this can prevent the formation of a hemolytic pore. The isolated action of $\mathrm{MZ}$ at concentrations of $5 \times 10^{-6}$ and higher causes a decrease in the hemolytic resistance of erythrocytes [16].

A significant increase in erythrocyte peroxide hemolysis occurs (experimental tests - $(8.36 \pm 0.34) \%$; control samples $(6.13 \pm 0.70) \%, \mathrm{p}<0.05)$ with the isolated action of $\mathrm{MZ}$ at a concentration of $250 \mu \mathrm{mol} / \mathrm{l}$. It should be noted that peroxide hemolysis under the action of MZ increases by $36 \%$, while under similar conditions, osmotic hemolysis - by $76 \%$.

A number of authors believe that damage to erythrocytes surface properties plays a decisive role in the mechanism of damage to erythrocyte membranes when modifying MZ [10,11], since MZ easily gives up a radical anion, which causes the destruction of DNA, RNA and other vital cellular macromolecules

\section{Література}

1. Бабак О.Я. Глутатион в норме и при патологии: биологическая роль и возможности клинического применения. Здоров'я України. 2015. № 1. С.1-3.

2. Баева Е.С., Артюхов В.Г. Пути реализации неантибактериальных эффектов антибиотиков, широко применяемых в клинической практике. Антибиотики и химиотерапия. 2019 T. 64. № 11-12. C. 72-80. DOI: 10.37489/0235-2990-2019-64-11-12-72-80

3. Вельш О.А., Филончикова Е.С., Трофимова Е.Е. Сравнительный анализ методик оценки перекисной резистентности эритроцитов на основе литературных данных. Научное обозрение. Педагогические науки. 2019. № 5-2. С. 52-54.

4. Изучение антиоксидантного звена глутатионовой системы в плазме крови и эриТ.В. Федорович, В.Н. Цымбал. Дерматологія та венерологія. 2015. № 1 (67). С. 34-40. 5. Курашова Н.А., Колесникова Л.И. Окислительный стресс при некоторых воспалительных и инфекционных заболеваниях урогенитального тракта у мужчин. Урология. 2018. № 1 C. 155-158. https://dx.doi.org/10.18565/urology.2018.1.155-158

6. Етіотропне лікування запальних захворювань сечостатевих органів / Г.І. Мавров, О.М. Борис, П.В. Федорич, С.К. Джораєва. Дерматологія та венерологія. 2017. № 3 (77). С. 70-75 7. Марзиева Т.А., Рогожина И.Е., Глухова Т.Н. О целесообразности использования анти оксидантов в комплексной терапии острого сальпингооофорита. Лечащий врач. 2021. № 3. 8. Махлай Н.С. Лабораторные методы диагностики урогенитального трихомоноза. Инфекция и иммунитет. 2011. Т. 1. № 3. С. 243-248.

9. Нарушение процессов перекисного окисления белков, липидов и антиоксидантной защиты при развитии бесплодия у больных хроническим простатитом на фоне инфекций, передающихся половым путем / Р.А. Садретдинов, О.С. Полунина, Л.П. Воронина, А.А. Полунин. Кубанский научный медицинский вестник. 2016. № 1 (156). С. 121-125. 10. Показатели адсорбционно-транспортной функции эритроцитов при действии метронидазола / З.Ш. Смагулова, С.Г. Макарушко, Т.Д. Ким, Х.М. Садыкова, Е.О. Остапчук. Вестник КазНУ. Серия биологическая. 2011. № 1 (47). С. 133-135.

11. Попыхова Э.Б. Возможные молекулярные механизмы реализации биологических эффектов метронидазола. Научный форум: Медицина, биология и химия: сб. ст. по материалам XXVI междунар. науч.-практ. конф. М.: МЦНО. 2019. № 8(26). С. 11-15.

12. Поступаленко А.В., Зайвелєва Ю.І., Зотов О.С. Система глутатіону - перспективна мішень для підвищення чутливості до хіміотерапевтичних препаратів (огляд літератури). Практична онкологія. 2019. T. 2. № 2. DOI: 10.22141/2663-3272.2.2.2019.176028

13. Реброва О.Ю. Статистический анализ медицинских данных: применение пакета приладних программ STATISTIKA. М.: МедиаСфера, 2000. 312 c.

14. Федорич П.В., Мавров Г.І. Сучасна клініко-епідеміологічна характеристика хворих на сечостатевий трихомоноз в Україні. Український журнал дерматології, венерології, косме ологіi. 2020. № 1 (76). С. 15-23. DOI: https://doi.org/10.30978/UJDVK2020-1-15

15. Helena C. Trichomoniasis in Pap Grow: How Gripping Right? European Journal of Experimental Biology. 2020. Vol.10. No.4. P.6.

Kunetsov P.E., Popykhova E.B., Rogacheva S.M., Evlakov K.I. The influence of the 1-(2'-hydroxiethyl)-2-methyl-5-nitroimidazole on the state of erythrocyte membranes and their
models. Biomeditsinskaia Khimiia. 2005. V. 51. N 6. P. 649-655.
Table 2. Influence of metronidazole on the level of hypotonic hemolysis of erythrocytes of healthy donors ( $\mathbf{M} \pm \sigma$, Wilcoxon test)

\begin{tabular}{|l|c|c|}
\hline \multirow{2}{*}{\multicolumn{1}{|c|}{ Test samples }} & \multicolumn{2}{|c|}{ Osmotic hemolysis, \% } \\
\cline { 2 - 3 } & $\begin{array}{c}77 \mathrm{mmol} / \mathrm{I} \mathrm{NaCl} \\
\text { solution }\end{array}$ & $\begin{array}{c}60 \mathrm{mmol} / \mathrm{l} \mathrm{NaCl} \\
\text { solution }\end{array}$ \\
\hline Intact erythrocytes (control) & $6,11 \pm 0,73$ & $45,80 \pm 5,77$ \\
\hline $\begin{array}{l}\text { Erythrocytes + } 80 \mu \mathrm{mol} / \mathrm{l} \\
\text { metronidazole }\end{array}$ & $4,64 \pm 0,96^{*}$ & $35,50 \pm 5,13^{*}$ \\
\hline $\begin{array}{l}\text { Erythrocytes + } 250 \mu \mathrm{mol} / \mathrm{l} \\
\text { metronidazole }\end{array}$ & $10,76 \pm 2,27^{*}$ & $65,40 \pm 9,07^{*}$ \\
\hline
\end{tabular}

Note: ${ }^{\star} p<0.05$ relative to intact erythrocytes.

[11]. The obtained data (Table 1) and literature data indicate that inhibition of the activity of the antioxidant system and activation of peroxide processes are observed in patients with urogenital trichomoniasis $[5,7,9]$. All this indicates the need to improve the therapy of urogenital trichomoniasis with the use of drugs that reduce the nonspecific effects of MZ.

\section{Conclusions}

1. It was shown that inhibition of the activity of the enzymatic link of antioxidant protection is observed in urogenital trichomoniasis - the activity of GP and GR in the erythrocytes of patients is significantly reduced, which is one of the mechanisms of the development of pathology at the cellular level in this disease.

2. It has been established that in vitro MZ causes structural modifications of plasma membranes: the drug at low concentration is able to inhibit hypotonic hemolysis of erythrocytes, and high concentration makes them more sensitive to the osmotic and peroxide hemolysis.

The obtained results must be taken into account when developing or improving complex methods of therapy for urogenital trichomoniasis.

\section{References} 1. Babak Ola. Glutation v norme i pri patologii: biologicheskaya rol i vozmozhnosti klinichesk-
ogo primeneniya [Glutathione in health and disease: biological role and clinical potential]. Health of Ukraine. 2015;1:1-3. [in Rus.]

2. Baeva ES, Artiukhov VG. Puti realizatsii neantibakterialnyih effektov antibiotikov, shiroko primenyaemyih $v$ klinicheskoy praktike [Ways of realizing non-antibacterial effects of antibiotics widely used in clinical practice]. Antibiotics and chemotherapy. 2019;64(11-12):72-80. [In Rus.] 3. Velsh OA, Filonchikova ES, Trofimova EE. Sravnitelnyiy analiz metodik otsenki perekisnoy rezistentnosti eritrotsitov na osnove literaturnyih dannyih. Nauchnoe obozrenie [Comparative analysis of methods for assessing erythrocyte peroxide resistance based on literature data. Scientific Review]. Pedagogical sciences. 2019;5-2:52-54. [In Rus.]

4. Kondakova AK, Bondarenko GM, Fedorovich TV, Tsymbal VN. Izuchenie antioksidantnogo zvena glutationovoy sistemyi v plazme krovi i eritrotsitah bolnyih urogenitalnyim mikoplazmozom [Study of the antioxidant link of the glutathione system in blood plasma and erythrocytes of patients with urogenital mycoplasmosis]. Dermatology and venereology. 2015;1(67):34-40. [In Rus.] 5. Kurashova NA, Kolesnikova LI. Okislitelnyiy stress pri nekotoryih vospalitelnyih i infektsionnyih zabolevaniyah urogenitalnogo trakta u muzhchin [Oxidative stress in some inflammatory and infectious diseases of the urogenital tract in men]. Urology. 2018;1:155-158. https://dx.doi. org/10.18565/urology.2018.1.155-158 [In Rus.]

6. Mavrov GI, Borys OM, Fedorych PV, Dzhorayeva SK. Etiotropne likuvannia zapalnykh zakhvoriuvan sechostatevykh orhaniv [Etiotropic treatment of inflammatory diseases of the urogenital organs]. Dermatology and venereology. 2017;3(77):70-75. [In Ukr.]

7. Marzieva TA, Rogozhina IE, Glukhova TN. O tselesoobraznosti ispolzovaniya antioksidantov $\checkmark$ kompleksnoy terapii ostrogo salpingoooforita [On the expediency of using antioxidants in the complex therapy of acute salpingo-oophoritis]. Attending doctor. 2021; 3. [In Rus.]

8. Makhlai NS. Laboratornyie metodyi diagnostiki urogenitalnogo trihomonoza [Laboratory methods for the diagnosis of urogenital trichomoniasis]. Infection and immunity. 2011;1(3):243248. [In Rus.]

9. Sadretdinov RA, Polunina OS, Voronina LP, Polunin AA. Narushenye protsessov perekysnoho okyslenyia belkov, lypydov y antyoksydantnoi zashchyty pry razvytyy besplodyia u bolnykh khronycheskym prostatytom na fone ynfektsyi, peredaiushchykhsia polovym putem [Violation of the processes of peroxidation of proteins, lipids and antioxidant protection during the development of infertility in patients with chronic prostatitis against the background of sexually transmited infections]. Kuban Scientific Medical Bulletin. 2016;1(156):121-125. [In Rus.]

10. Smagulova ZSh, Makarushko SG, Kim TD, Sadykova KhM, Ostapchuk EO. Narushenie protsessov perekisnogo okisleniya belkov, lipidov i antioksidantnoy zaschityi pri razvitii besplodiya u bolnyih hronicheskim prostatitom na fone infektsiy, peredayuschihsya polovyim putem [Indicators of the adsorption-transport function of erythrocytes under the action of me zole]. KazNU Bulletin. Biological series. 2011;1(47):133-135. [In Rus.]

11. Popykhova EB. Vozmozhnyie molekulyarnyie mehanizmyi realizatsii biologicheskih effektov metronidazola [Possible molecular mechanisms of realization of the biological effects of metronidazole]. Scientific forum. Medicine, biology and chemistry: collection of articles. Art. based 12. Poals XXVI international. scientific-practical conf. M. MCNO. 2019,8(26):11-15. [In Rus.] 12. Postupalenko AV, Zaiveleva Yul, Zotov OS. Systema hlutationu - perspektyna mishen dila pidvyshche system is a promising target for increasing sensitivity to chemotherapy drugs (literature review)]
Practical Oncology. 2019;2(2). DOI: 10.22141 / 2663-3272.2.2.2019.176028 13 [In Ukr.] 
13. Rebrova Olu Statisticheskiy analiz meditsinskih dannyih: primenenie paketa prikladnih programm STATISTIKA [Statistical analysis of medical data: using the STATISTIKA software packge]. M: MediaSfera, 2000. 312 p. [In Rus.]

4. Fedorych PV, Mavrov Gl. Suchasna kliniko-epidemiolohichna kharakterystyka khvorykh na sechostatevyi trykhomonoz v Ukraini [Modern clinical and epidemiological characteristics of patients with urogenital trichomoniasis in Ukraine]. Ukrainian Journal of Dermatology, Venereolog

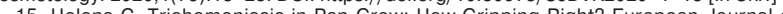
Experimental Biology. 2020;10(4):6.

16. Kuznetsov PE, Popykhova EB, Rogacheva SM, Evlakov KI. The influence of the

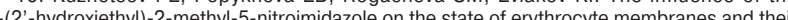
models. Biomeditsinskaia Khimiia. 2005:51(6):649-655.

\title{
СОСТОЯНИЕ АНТИОКСИДАНТНОЙ СИСТЕМЫ ПРИ УРОГЕНИТАЛЬНОМ ТРИХОМОНИАЗЕ И МЕМБРАНОТРОПНОЕ ДЕЙСТВИЕ МЕТРОНИДАЗОЛА
}

\author{
А.К. Кондакова, Г.А. Семко, Е.В. Левицкая, В.Н. Цимбал \\ ГУ «Институт дерматологии и венерологии НАМН Украины»
}

\section{Резюме}

Цель работы - изучение активности глутатионпероксидазы, глутатионредуктазы и уровня сульфгидрильных групп в эритроцитах больных урогенитальным трихомониазом и влияния метронидазола на степень осмотической и перекисной резистентности эритроцитов здоровых доноров.

Было обследовано 15 пациентов с урогенитальным трихомониазом и 20 здоровых доноров. Для идентификации Trichomonas vaginalis исследовали нативные препараты, а также проводили культуральный метод с использованием среды Джонсона - Трасселя (CPLM). В эритроцитах периферической крови определяли активность глутатионредуктазы, глутатионпероксидазы и уровень общих сульфгидрильных групп. Мембранотропное действие метронидазола оценивали в эксперименте in vitro по степени осмотической и перекисной резистентности эритроцитов здоровых лиц. Установлено, что у больных урогенитальным трихомониазом наблюдается значительное снижение активности глутатионредуктазы и глутатионпероксидазы в эритроцитах, что свидетельствует о нарушении антиоксидантной системы при данной патологии. В эксперименте in vitro показано, что метронидазол в малых концентрациях (80 мкмоль/л) обладает способностью блокировать гипотонический гемолиз эритроцитов, а в высокой (250 мкмоль/л) - приводит к усилению гипотонического и перекисного гемолиза эритроцитов. Таким образом, при урогенитальном трихомониазе наблюдается угнетение активности ферментативного звена антиоксидантной защиты, что является одним из механизмов развития патологии на клеточном уровне при данном заболевании. Показано, что изолированное мембранотропное действие метронидазола зависит от его концентрации: в малой концентрации препарат блокирует осмотический гемолиз, а высокая концентрация приводит к повышению чувствительности эритроцитов к осмотическому и перекисному гемолизу. Полученные результаты необходимо учитывать при разработке комплексных методов терапии урогенитального трихомониаза.

Ключевые слова: урогенитальный трихомониаз, антиоксидантная система, осмотический гемолиз, перекисный гемолиз, метронидазол.

\section{СТАН АНТИОКСИДАНТНОЇ СИСТЕМИ ПРИ УРОГЕНІТАЛЬНОМУ ТРИХОМОНІАЗІ ТА МЕМБРАНОТРОПНА ДІЯ МЕТРОНІДАЗОЛУ}

Г.К. Кондакова, Г.О. Семко, О.В. Левицька, В.М. Цимбал

ДУ «Інститут дерматології та венерології НАМН України»

\section{Резюме}

Мета роботи - вивчення активності глутатіонпероксидази, глутатіонредуктази та рівня сульфгідрильних груп в еритроцитах хворих на урогенітальний трихомоніаз та впливу метронідазолу на ступінь осмотичної та перекисної резистентності еритроцитів здорових донорів.

Було обстежено 15 пацієнтів з урогенітальним трихомоніазом і 20 здорових донорів. Для ідентифікації Trichomonas vaginalis досліджували нативні препарати, а також проводили культуральний метод з використанням поживного середовища Джонсона Траселя (CPLM). В еритроцитах периферичної крові визначали активність глутатіонредуктази, глутатіонпероксидази та рівень загальних сульфгідрильних груп. Мембранотропну дію метронідазолу оцінювали в експерименті in vitro за ступенем осмотичної та перекисної резистентності еритроцитів здорових донорів. Встановлено, що ухворих на урогенітальний трихомоніаз спостерігається значне зниження активності глутатіонредуктази та глутатіонпероксидази в еритроцитах, що свідчить про порушення антиоксидантної системи при цій патології. В експерименті in vitro показано, що метронідазол у малих концентраціях (80 мкмоль/л) має властивість блокувати гіпотонічний гемоліз еритроцитів, а у високій (250 мкмоль/л) - призводить до посилення гіпотонічного та перекисного гемолізу еритроцитів. Таким чином, при урогенітальному трихомоніазі спостерігається пригнічення активності ферментативного ланцюга антиоксидантного захисту, що може бути одним із механізмів розвитку патології при трихомоніазі. Показано, що ізольована мембранотропна дія метронідазолу залежить від його концентрації: в малій концентрації препарат блокує осмотичний гемоліз, а висока концентрація призводить до підвищення чутливості еритроцитів до осмотичного і перекисного гемолізу. Одержані результати необхідно враховувати при розробці комплексних методів терапії урогенітального трихомоніазу.

Ключові слова: урогенітальний трихомоніаз, антиоксидантна система, осмотичний гемоліз, перекисний гемоліз, метронідазол.

\section{Відомості про авторів:}

Кондакова Ганна Костянтинівна - канд. біол. наук, завідувач лабораторії біохімії ду «/нститут дерматології та венерології НАМН України», e-mail: anakondak@gmail.com

ORCID ID: https://orcid.org/0000-0002-7739-1922

Семко Галина Олександрівна - канд. біол. наук, ст. наук. співроб. лабораторії біохімії Ду «Інститут дерматології та венерології НАМН України», e-mail: semkogalina@ukr.net

ORCID ID: https://orcid.org/0000-0002-9465-224X

Левицька Олена В'ячеславівна - мол. наук. співроб. лабораторії біохімії Ду «Інститут дерматології та венерології НАМН України», e-mail: elena.vyacheslavovna.e@gmail.com

ORCID ID: https://orcid.org/0000-0002-9774-2179

Цимбал Вікторія Миколаївна - мол. наук. співроб. лабораторії біохімії Ду «Інститут дерматології та венерології НАМн України», e-mail: viktorya.zmb/@gmail.com

ORCID ID: https://orcid.org/0000-0002-6673-3835 